\title{
KECEMASAN KELUARGA DALAM MERAWAT KLIEN SKIZOFRENIA
}

\author{
Tantan Hadiansyah ${ }^{1}$, Andria Pragholapati ${ }^{2}$ \\ 1) Akper Dustira, Keperawatan, Cimahi \\ 2) Universitas Pendidikan Indonesia, Bandung \\ tantan.hadiansyah78@gmail.com
}

\begin{abstract}
ABSTRAK
Data penderita gangguan jiwa berat di wilayah Indonesia sebagian besar berada di masyarakat dibandingkan di rumah sakit. Perbaikan kondisi skizofrenia sangat terkait dengan keterlibatan keluarga dalam kehidupan skizofrenia. Keluarga yang merawat anggota keluarga yang dengan skizofrenia mengalami gangguan psikologis penelitian ini menggunakan metode deskriptif kuantitatif. Sampel berjumlah 24 responden dengan teknik non probability sampling dengan metoda consecutive sampling dengan kriteria anggota keluarga yang merawat anggota keluarga skizofrenia di Puskesmas Melong Asih Kota Cimahi. Instrumen penelitian menggunakan zung's self-rating anxiety scale. Tingkat kecemasan yang dialami oleh anggota keluarga yang merawat penderita skizofrenia sebagian besar responden (79\%) berada pada skor kecemasan sedang dan 21\% responden mengalami kecemasan yang berat. kecemasan berat ini dimanifestasikan dengan adanya gangguan terhadap aktivitas sehari-hari pada anggota keluarga yang merawat penderita skizofrenia. Saran dukungan keluarga diharapkan dapat dimasukan sebagai salah satu bagian dari penanganan kecemasan pada anggota keluarga yang merawat anggota keluarga skizofrenia.
\end{abstract}

Kata kunci : gangguan jiwa berat, keluarga, tingkat kecemasan, skizofrenia

\section{Abstract}

Data of people with severe mental disorders in Indonesia are mostly in the community compared to hospitals. Improvement of schizophrenia is closely related to family involvement in schizophrenic life. Families who care for family members with schizophrenia experience psychological disorders in this study using quantitative descriptive methods. The sample consisted of 24 respondents with non-probability sampling techniques with a consecutive sampling method with criteria for family members caring for schizophrenic family members in the puskesmas as long as cimahi city. The research instrument uses zung's self-rating anxiety scale. the level of anxiety experienced by family members caring for schizophrenics most of the respondents (79\%) was at moderate anxiety scores and $21 \%$ of respondents experienced severe anxiety. severe anxiety is manifested by the disruption of daily activities in family members who care for schizophrenics. It is hoped that family support recommendations can be included as part of the handling of anxiety in family members caring for schizophrenic family members.

Keywords: anxiety level, family, schizophrenia, severe mental disorders 


\section{PENDAHULUAN}

Di seluruh dunia, skizofrenia dikaitkan dengan kecacatan yang cukup besar dan dapat memengaruhi kinerja pendidikan dan pekerjaan. Skizofrenia adalah gangguan mental kronis dan parah yang menyerang 20 juta orang di seluruh dunia (WHO, 2019). WHO (2016), terdapat 21 juta terkena skizofrenia. Data Riset Kesehatan Dasar tahun 2018 di Indonesia terdapat skizofrenia mencapai sekitar 400.000 orang atau sebanyak 1,7 per 1.000 penduduk (Depkes RI., 2019). Kota Cimahi menempati urutan ke-6 tertinggi di Jawa Barat dengan jumlah penderita gangguan jiwa sebanyak $14.4 \%$. Penderita gangguan jiwa berat skizofrenia di Indonesia sebagian besar berada di masyarakat dibandingkan di Rumah Sakit (Riskesdas, 2018).

Skizofrenia adalah penyakit mental serius yang ditandai oleh pikiran yang tidak koheren, perilaku aneh, ucapan aneh, dan halusinasi, seperti mendengar suara (APA, 2020b). Skizofrenia dapat diobati. Perawatan dengan obat-obatan dan dukungan psikososial efektif. Fasilitasi hidup yang dibantu, perumahan yang didukung dan pekerjaan yang didukung adalah strategi manajemen yang efektif untuk orang dengan skizofrenia (WHO, 2019).

Skizofrenia dikaitkan dengan kecacatan yang cukup dan dapat mempengaruhi kinerja pendidikan dan pekerjaan. Orang dengan skizofrenia 2 - 3 kali lebih mungkin meninggal lebih awal daripada populasi umum. Ini sering disebabkan oleh penyakit fisik, seperti penyakit kardiovaskular, metabolisme, dan infeksi. Stigma, diskriminasi dan pelanggaran hak asasi manusia dari penderita skizofrenia adalah hal biasa (WHO, 2019). Perbaikan kondisi skizofrenia sangat terkait dengan keterlibatan keluarga dalam kehidupan skizofrenia. Anggota keluarga dapat meringankan kesulitan penyakit mental serius ini dengan cara yang tidak bisa dilakukan orang di luar sistem keluarga (Olson, 2014).
Anggota keluarga berhubungan dekat dengan penderita skizofrenia, mereka lebih mampu memantau perilaku penderita skizofrenia. Mereka tahu anggota keluarga ini, dan mereka bisa memastikan penyebab perilaku negatif penderita skizofrenia. Pemahaman yang lebih dekat ini memungkinkan mereka untuk melakukan intervensi secara proaktif dan sebelum perilaku bergejala negatif muncul (Olson, 2014).

Keluarga adalah aspek penting dalam proses pemulihan orang dengan skizofrenia. Keluarga sebagai sumber dukungan dibutuhkan oleh pasien setiap hari untuk menyelesaikan proses penyembuhan mereka. Keluarga dalam pemulihan orang dengan skizofrenia, yaitu: (1) pengawasan minum obat, (2) memberikan perawatan yang berkesinambungan dan optimal, dan (3) memberdayakan orang dengan skizofrenia (Purba, Simamora, Karota, \& Siregar, 2020)

Keluarga mengalami beban yang sangat besar dan mempunyai dampak negatif (Devaramane, 2011). Beban yang dirasakan keluargaakanmempengaruhiperawatanpenderita gangguan jiwa (Sadock \& Ruiz, 2015). Keluarga yang merawat anggota keluarga yang dengan skizofrenia mengalami gangguan psikologis (Mitsonis, et al, 2012). Gangguan psikologis yang dialami keluarga yaitu stres, frustasi, kurangnya interaksi sosial, harga diri menurun, depresi dan kecemasan (Cabral, Duartea, Ferreiraa, Santos, 2014; Vazquez, et.al, 2013). Anggota keluarga yang merawat penderita skizofrenia mengalami gangguan psikologis antara lain stres, frustrasi, kurangnya interaksi sosial, menurunnya harga diri, depresi dan kecemasan, kualitas hidup dan kualitas perawatan menurun, selama merawat anggota keluarga dengan skizofrenia (Mitsonis, et al., 2012; Rodrigo, Fernando, Rajapakse, De Silva, \& Hanwella, 2013; Shah, Sultan, Faisal, \& Irfan, 2013), (Fleming, et al., 2006). (Cabral, L., Duartea, J., Ferreiraa, M., Santos, C., 2014). 
Tujuan dalam penelitian ini adalah untuk mengetahui tingkat kecemasan yang dialami oleh anggota keluarga yang merawat penderita skizofrenia di Puskesmas Melong Asih Kota Cimahi.

\section{METODOLOGI}

Penelitian ini menggunakan metode deskriptif kuantitatif. Tujuan penelitian ini untuk memberikan gambaran tingkat kecemasan keluarga dalam merawatklien skizofrenia. Populasi penelitian yaitu seluruh keluarga yang merawat pasien skizofrenia yang ada di Puskesmas Melong Asih Kota Cimahi sebanyak 75 orang. Teknik pengambilan sampel dengan metoda Consecutive Sampling dengan kriteria anggota keluarga yang merawat anggota keluarga yang skizofrenia selama 6 bulan ke atas, berkomunikasi dengan baik, dapat menulis, keluarga tinggal satu rumah dengan anggota keluarga skizofrenia, dan berusia lebih dari 18 tahun, sehingga sampel berjumlah 24 orang. Instrumen yang digunakan kuesioner kecemasan Zung's Self-Rating Anxiety Scale (Zung, 1971), . Hasil uji validitas dan reliabilitas Zung's Self-Rating Anxiety Scale adalah semua item pernyataan valid dengan nilai validitas $>0,444$ dan hasil uji reliabilitas menggunakan nilai alpha cronbach, dan nilai hasil uji nya adalah 0,887 (Muliani, Pragholapati, \& Irman, 2020).

\section{HASIL}

Tabel 1. Gambaran Tingkat kecemasan keluarga dalam merawat klien skizofrenia

\begin{tabular}{lcc}
\hline Tingkat Kecemasan & f & \% \\
\hline Sedang & 19 & 79 \\
Berat & 5 & 21 \\
\hline Total & 24 & 100 \\
\hline
\end{tabular}

Dari tabel 1 menunjukkan data bahwa sebagian besar responden (79\%) berada pada skor kecemasan sedang dan (21\%) responden mengalami kecemasan yang berat sehingga gejala yang muncul pada anggota keluarga yang merawat penderita skizofrenia menimbulkan gangguan terhadap aktivitas sehari-hari.

\section{PEMBAHASAN}

Anggota keluarga yang merawat penderita skizofrenia memiliki kecemasan yang sedang hal ini sejalan dengan penelitian Cabral, L., Duartea, J., Ferreiraa, M., Santos, C. (2014) bahwa kecemasan adalah yang paling sering terjadi pada keluarga yang merawat anggota keluarga dengan skizofrenia. Tingkat kecemasan bervariasi mulai dari cemas ringan sampai cemas berat tergantung dari mekanisme koping yang dimiliki oleh keluarga tersebut dan kekuatan faktor-faktor yang memengaruhi terjadinya kecemasan itu sendiri. Didukung oleh penelitian Vazquez, et.al, (2013) bahwa keluarga yang merawat anggota keluarga dengan skizofrenia memiliki gejala kecemasan.

Kecemasan adalah emosi yang ditandai oleh perasaan tegang, pikiran cemas, dan perubahan fisik seperti peningkatan tekanan darah. Orang dengan gangguan kecemasan biasanya memiliki pikiran atau masalah yang mengganggu berulang. Mereka mungkin menghindari situasi tertentu karena khawatir. Mereka mungkin juga memiliki gejala fisik seperti berkeringat, gemetar, pusing atau detak jantung yang cepat (APA, 2020a). Kecemasan saat ini ditandai oleh banyak kognitif subyektif (kecemasan antisipatif), perilaku (perilaku penghindaran) dan psikologis (khawatir, takut). Aspek kecemasan, somatik atau komorbiditas merupakan tanda yang sering terjadi. Kecemasan sering kurang terdiagnosis dan tidak diobati dan merupakan beban ekonomi (Bulbena-Cabre, A., \& Bulbena, A., 2018). Menurut penelitian Kristian, I. wayan A., Sumirta, I. N., Suarnata, I. K., \& Muryani, N. M. (2019) sebagian besar keluarga pasien skizofrenia mengalami kecemasan ringan yaitu sebanyak 12 dengan gejala sering merasa lesu, 
kedutan otot, gemetar, dan sering merasa napas pendek. Dalam penelitian Wisanti, J., \& Suerni, T. (2018) anggota keluarga mengalami kecemasan dapat diketahui dengan melihat gejala kognitif, fisik, dan emosional.

Anggota keluarga yang merawat keluarga yang Skizofrenia mengalami Kecemasan berat. Begitu juga penelitian yang dilakukan Wisanti, J., \& Suerni, T. (2018) anggota keluarga mengalami kecemasan berat hanya sebesar 5,2\% hal ini terjadi kemungkinan dikarenakan ada hal lain yang juga memicu kecemasan yang berasal dari faktor eksternal status ekonomi, hubungan interpersonal, dan sosial budaya.

Perananan keluarga sangat diperlukan untuk membantu pemulihan penderitan dan mencegah kekambuhan yaitu melalui dukungan emosional yang diberikan kepada penderita dan menghindari sikap permusuhan terhadap penderita, keluaga juga mempunyai peran penting dan mereka harus waspada dan mengawasi penderita setiap saat. Mereka juga membantu penderita dalam kegiatan sehari-hari untuk mengurangi ketegangan perasaan, keluarga juga harus membantu untuk memberikan obat pada penderita dan membawanya untuk periksa ulang.

\section{SIMPULAN DAN SARAN}

Gambaran tingkat kecemasan yang dialami oleh anggota keluarga yang merawat penderita skizofrenia yaitu sebagian besar responden berada pada skor kecemasan sedang dan responden mengalami kecemasan yang berat sehingga gejala yang muncul pada anggota keluarga yang merawat penderita skizofrenia menimbulkan gangguan terhadap aktivitas sehari-hari.

Saran dukungan keluarga diharapkan dapat dimasukan sebagai salah satu bagian dari penanganan kecemasan pada anggota keluarga yang merawat anggota keluarga Skizofrenia.

\section{DAFTAR PUSTAKA}

APA. (2020a). Anxiety. American Psychological Association. Retrieved from https://www. apa.org/topics/anxiety/.

APA. (2020b). Anxiety. American Psychological Association. Retrieved from https://www. apa.org/topics/schiz/.

Bulbena-Cabre, A., \& Bulbena, A. (2018). Schizophrenia and anxiety: yes, they are relatives not just neighbours. The British Journal of Psychiatry, 213(2), 498-498. doi:10.1192/bjp.2018.126

Cabral, L., Duarte, J., Ferreira, M., Santos, C., (2014). Anxiety, stress and depression in family caregivers of the mentally ill. Aten Primaria, 46, 176-179.

Devaramane, V. (2011). The effect of a brief family intervention on primary carer's fungtioning and their schizophrenic relatives levels of psychopatology in India. Asian journal of psychiatry. 4 (3): 183-187.

Depkes RI. (2019). Riset Kesehatan Dasar 2018. Jakarta. Badan Penelitian dan Pengembangan Kesehatan Republik Indonesia.

Fleming, D. A., Sheppard, V. B., Mangan, P. A., Taylor, K. L., Tallarico, M., Adams, I., \& Ingham, J. (2006). Caregiving at the end of life: Perceptions of health care quality and quality of life among patients and caregivers. Journal of Pain and Symptom Management, 31, 407-420.

Kristian, I. wayan A., Sumirta, I. N., Suarnata, I. K., \& Muryani, N. M. (2019). Gambaran Tingkat Kecemasan Keluarga dengan salah satu anggota Keluarganya Menderita Skizofrenia di Poliklinik Jiwa Rumah sakit Jiwa Provinsi Bali tahun 2012. Jurnal Kesehatan Medika Udayana, 5(01), 1-9. Retrieved from http://ejurnal. akperkesdamudayana.ac.id/index.php/ 
jmu/article/view/59

Mitsonis, C., Voussoura, E., Dimopoulos, N., Psarra, V., Kararizou, E., Latzouraki, E., ... Katsanou, M. -N. (2012). Factors associated with caregiver psychological distress in chronic schizophrenia. Social Psychiatry and Psychiatric Epidemiology, 47, 331-337.

Muliani, R, Pragholapati, P \& Irman. (2020). Pengaruh Komunikasi Terapeutik Perawat Terhadap Tingkat Kecemasan Keluarga Pasien Di Ruang Intensif RSUD Majalaya. HIJP : Health Information Jurnal Penelitian.

Olson, A. (2014). The Family of Schizophrenia. Psychology Today. http://www. psychologytoday.com/blog/theory-andpsychopathology/201411/the-familyschizophrenia

Purba, J. M., Simamora, R. H., Karota, E., \& Siregar, C. T. (2020). Family support for persons with schizophrenia after physical restraint and confinement. Enfermería Clínica, 30, 53-56.

Rodrigo, C., Fernando, T., Rajapakse, S., De Silva, V., \& Hanwella, R. (2013). Caregiver strain and symptoms of depression among principal caregivers of patients with schizophrenia and bipolar affective disorder in Sri Lanka.
International Journal of Mental Health Systems, 7, 2-7

Shah, S. T. H., Sultan, S. M., Faisal, M., \& Irfan, M. (2013). Psychological distress among caregivers of patients with schizophrenia. Journal of Ayub Medical College, Abbottabad: JAMC, 25, 27-30.

Sadock, B., \& Ruiz, P. (2015). Kaplan \& Sadock's synopsis of psychiatry: Behavioral sciences. Walters Kluwer.

Wisanti, J., \& Suerni, T. (2018). Tingkat Kecemasan Keluarga Menghadapi Kepulangan Anggota Keluarga Yang Mengalami Skizofrenia Di Rsjd Dr. Amino Gondohutomo Provinsi Jawa Tengah. Jurnal Ilmu Keperawatan dan Kebidanan, 10(2)

WHO, (2014). The world Health Report 2014 ; Mental Health New Understanding, New Hope.

WHO. (2019, October 4). Schizophrenia. https:// www.who.int/news-room/fact-sheets/ detail/schizophrenia

WHO. (2006). The lancet. London : Elsevier Properties SA.

Zung, W. W. K. (1971). A Rating Instrumen for Anxiety Disorder. Psychosomatics. 
